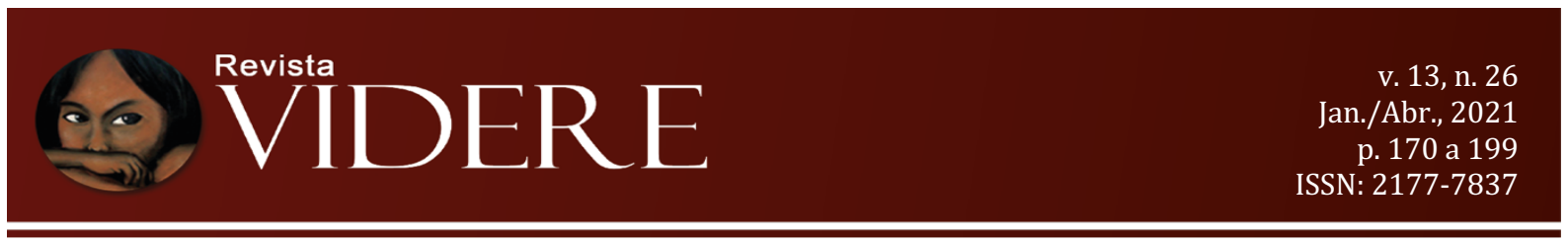

\title{
A PERSPECTIVA DESCOLONIAL
}

\author{
THE DECOLONIAL PERSPECTIVE
}

LA PERSPECTIVA DESCOLONIAL

\begin{abstract}
Marília Nascimento de Sousa
Mestra e Doutoranda em Direito

Programa de Pós-Graduação em Direito da Universidade Federal de Santa Catarina

(PPGD/UFSC)

Bolsista do CNPq

mariliansousa@outlook.com

OrcidID: https://orcid.org/0000-0002-6364-5661
\end{abstract}

\begin{abstract}
Resumo: Este artigo observa elementos da perspectiva descolonial e implicações no âmbito jurídico. Para tanto, pontua a constituição e as provocações do programa de pesquisa modernidade/colonialidade, que se apresenta como um pensamento de fronteira, e sua metodologia revela uma dupla crítica à modernidade desde a perspectiva da colonialidade. Apresenta-se como um diálogo com a modernidade desde as perspectivas subalternas, em resposta epistêmica, trazendo seus elementos enquanto discurso crítico para abordar os fenômenos da colonialidade do poder e da diferença colonial. Com isso, é questionado se a abordagem descolonial difere do discurso hegemônico. Desde os processos liberatórios latinoamericanos, é notado que a lógica colonial submete os sujeitos históricos do Sul global a permanentes, crescentes e precárias condições de vida. O raciocínio empreendido nessa discussão é dedutivo e, nesse momento, apresentado para compreender essa perspectiva descolonial de pensamento emergente na América Latina. Assim, o cerne da pesquisa consiste em uma análise da abordagem do pensamento descolonial.
\end{abstract}

Palavras-chave: Lógica Colonial. Colonialidade. Descolonização.

Abstract: This article observes elements of the decolonial perspective and implications in the legal sphere. In order to do that, it punctuates the constitution and the provocations of the modernity/coloniality research program, which presents itself as a frontier thought, and its methodology reveals a double criticism of modernity from the perspective of coloniality. It presents itself as a dialogue with modernity from the subordinate perspectives, in an epistemic response, bringing its elements as a critical discourse to approach the phenomena of the coloniality of power and the colonial difference. As a result, it is questioned whether the decolonial approach differs from the hegemonic discourse. Since the Latin American liberation processes, it is noted that the colonial logic submits the historical subjects of the global South to permanent, growing and precarious conditions of life. The reasoning undertaken in this 
discussion is deductive and, at that moment, presented to understand this decolonial perspective of emerging thought in Latin America. Thus, the core of the research consists of an analysis of the decolonial thinking approach.

Keywords: Colonial Logic. Coloniality. Decolonization.

Resumen: Este trabajo analiza elementos desde la perspectiva descolonial y las implicaciones en el ámbito legal. Para ello, puntúa la constitución y provocaciones del programa de investigación modernidad/colonialidad que se presenta como un pensamiento de frontera y su metodología revela una doble crítica a la modernidad desde la perspectiva de la colonialidad. Se presenta como un diálogo con la modernidad desde las perspectivas subordinadas, en una respuesta epistémica, trayendo sus elementos como discurso crítico para abordar los fenómenos de la colonialidad del poder y la diferencia colonial. En consecuencia, es cuestionado si el enfoque descolonial difiere del discurso hegemónico. Desde los procesos de liberación latinoamericanos, es notado que la lógica colonial somete a los sujetos históricos del Sur global a condiciones de vida permanentes, crecientes y precarias. El razonamiento emprendido en esta discusión es deductivo $\mathrm{y}$, en ese momento, presentado para comprender esta perspectiva descolonial del pensamiento emergente en América Latina. Por tanto, el núcleo de la investigación consiste en un análisis de la enfoque del pensamiento descolonial.

Palabras clave: Lógica colonial. Colonialidad. Descolonización

\section{Introdução}

A emergência do pensamento descolonial no contexto dos processos de descolonização da América Latina, África e Ásia, sob as influências de teorias como as póscoloniais, proporciona elementos para repensar a estrutura de poder colonial que perpassa os fundamentos estruturadores dessas sociedades.

“A perspectiva descolonial" propõe a abordagem do pensamento descolonial a partir do contexto e da constituição de um programa de pesquisa denominado modernidade/colonialidade, girando entorno da descolonização nas sociedades do Sul global, na particularidade da América Latina. Destaca as fronteiras que constituem essa realidade sob o auspício de uma práxis intercultural, propondo pensar desde a fronteira.

Dispõe a justificativa da opção descolonial. Como uma posição contra-hegemônica à lógica do capital empreendida nestas sociedades periféricas "encobertas" desde o nascimento da modernidade em 1492, com a invasão da América e a Era do Sexto Sol, conforme uma cosmovisão indígena, que representa o "fim" do seu mundo com a chegada do sujeito alémmar. 
A partir dos elementos do discurso crítico do pensamento descolonial, a forma contrahegemônica de produção alternativa salienta a supressão histórica da satisfação das necessidades básicas dos sujeitos no Sul global.

\section{0 programa modernidade/colonialidade}

No século XX, ocorreram processos de descolonização do mundo para uma modificação das estruturas jurídico-políticas da periferia global. Após 450 anos, as eliminações das administrações coloniais pareciam caracterizar um mundo "pós-colonial", um dos mais poderosos mitos daquele século. Todavia, essas regiões permanecem submetidas à mesma matriz de poder colonial, não mais em um período de colonialismo global, mas se tratando de uma colonialidade global (GROSFOGUEL, 2008, p. 126).

Durante o período pós-guerra, emergem pensamentos que seriam chamados de póscoloniais e, posteriormente, de/descoloniais. O prefixo "pós", de pós-colonialismo, não se relaciona a uma suspensão dos efeitos do domínio colonial, mas sinaliza que os conflitos de poder e os regimes de poder-saber permanecem nas nações pós-coloniais. Das lições de Stuart Hall, Costa e Grosfoguel (2016, p. 1) denota-se que a relevância dos primeiros passos constatados nos estudos pós-coloniais é a capacidade de promover uma outra leitura da colonização do tempo presente, desde escritas descentradas ou de narrativas imperiais do passado.

A genealogia da teoria pós-colonial remete aos processos políticos pós-guerra de descolonização na África e na Ásia, durante a segunda metade do século XX. A discussão nasce inscrita na experiência da colonização britânica ocorrida, sobretudo, na Ásia com Gayatri Spivak, Ranajit Guha, Edward Said e Homi Bhabha no sul asiático, os quais desenvolveram essa matriz teórica. E, a partir dos anos 70, processou-se em algumas universidades norteamericanas e inglesas.

Essa teoria protagonizada, principalmente, por intelectuais nos departamentos de estudos culturais, em universidades inglesas e norte-americanas, posteriormente, torna evidente que a língua de nascença do pós-colonialismo é a inglesa, tendo circulado nesse mundo anglofônico, razão da existência de conceitos e expressões inglesas no desenvolvimento tanto dos pós-coloniais quanto dos descoloniais.

Nesse primeiro momento de reflexão pós-colonial, há a constituição do Grupo de Estudos da Subalternidade do Sul da Ásia (GESSA), que deriva do pós-colonialismo e 
objetivava desconstruir a razão colonial e nacionalista da Índia para restituir a pluralidade e descentralidade dos sujeitos subalternos. As publicações do grupo surgem como propostas pedagógicas de aprendizado da consciência subalterna silenciada no e pelo discurso oficial, no caminho das fissuras e contradições deste para uma emancipação (GROSFOGUEL; COSTA, 2016, p. 16).

O pós-colonialismo está inserido no pós-estruturalismo, no desconstrutivismo e no pós-modernismo, razão pela qual tem seus pontos de apoio em Michel Foucault, Jaques Derrida e Jaques Lacan. Os clássicos do pensamento pós-colonial que identificam essa linha epistemológica são: Albert Memmi ("Retrato do colonizado precedido de retrato do colonizador, 1947”); Aimé Césaire, Discurs sur le Colonialisme ("Discurso sobre o Colonialismo", de 1950); Frantz Fanon, Les Dámnes de la Terre (“Os Condenados da Terra”, de 1961); Edward Said, Orientalism (“Orientalismo”, de 1978). O rol também inclui Deleuze, Marx, e os mais contemporâneos Partha Chatterjee e Boaventura de Sousa Santos (SOARES; RODRIGUES, 2016, p. 497).

Naquele momento dos pós-coloniais, em uma contextualização do pensamento crítico latino-americano do século XX, mais precisamente das décadas de $1960^{1}$ e 1970, muitos estudiosos já desenvolviam linhas próprias de pensamento e significativos fatores de influência na constituição da genealogia/identidade do pensamento daquele grupo emergente pós-colonial no movimento mundial de novas formas de pensar atentas às classes oprimidas e negadas.

Os anos 1960 e 1970 já contavam com a Teologia da Libertação e com os debates na filosofia e ciência social latino-americana sobre noções como Filosofia da Libertação e uma Ciência Social autônoma com Enrique Dussel, Rodolfo Kusch, Orlando Fals Borba, Pablo Gonzáles Casanova e Darcy Ribeiro (SOARES; RODRIGUES, 2016, p. 483). O conceito de colonialismo interno, apoiado no eixo racial, elaborado por Pablo Gonzales Casanova, na

1"Desde o final da década de 1960, como fruto do surgimento das ciências sociais críticas latino-americanas (especialmente a 'teoria da dependência'), como também da obra "Totalidade e infinito" de Emmanuel Levinas (1988), e principalmente pelos movimentos populares e estudantis de 1968 (no mundo, notadamente na Argentina e América Latina), se produziu no campo da filosofia, portanto na filosofia da cultura, uma ruptura histórica. $\mathrm{O}$ que havia sido considerado como mundo metropolitano e mundo colonial agora era classificado (a partir da terminologia, ainda desenvolvimentista, de Raúl Presbish - Cepal) como 'centro' e 'periferia'. A isso se deve agregar todo um horizonte categórico proveniente da economia crítica, que exigia a incorporação das classes sociais como atores intersubjetivos a serem integrados a uma definição de cultura. Não se tratava de mera questão terminológica e sim conceitual, que permitia romper com o conceito 'substancialista' da cultura, descobrindo suas fraturas internas (dentro de cada cultura) e entre elas (não só como 'diálogo' ou 'choque intercultural, mas estritamente como dominação e exploração de uma sobre as demais". A assimetria dos atores deveria ser levada em conta em todos os níveis. A etapa 'culturalista' tinha acabado” (DUSSEL, 2016, p. 51). 
década de 60, alude à fronteira interna do império ${ }^{2}$. Em suma, tem-se Dussel com a Filosofia da Libertação, Quijano com a Colonialidade do poder, Theotônio dos Santos e Rui Marini com Teoria da Dependência e Wallerstein com a Teoria do Sistema-Mundo.

Embora a América Latina tenha histórico colonial e de reação a seus efeitos, havia um silêncio ou uma não observância nos estudos pós-coloniais às contribuições de seus intelectuais, não tendo qualquer referência à América Latina por parte de tais estudiosos. Por essas e outras questões, na virada do milênio constituiu-se uma rede de pesquisa por intelectuais latinoamericanos em torno da decolonialidade - o programa Modernidade/Colonialidade $(\mathrm{M} / \mathrm{C})$ (GROSFOGUEL; COSTA, 2016, p. 16).

A primeira forma de inserção da América Latina no debate pós-colonial, inspirada no Grupo de Estudos Subalternos do sul asiático (GESSA), se deu com o grupo de intelectuais latino-americanos e americanistas, o Grupo Latino-Americano dos Estudos Subalterno $(\mathrm{GLAES})^{3}$, originalmente constituído por Ileana Rodríguez, John Berverley, Robert Carr, José Rabasa e Javier Sanjiné, que em terras norte-americanas publicou seu Founding Statement na revista Boundary 2, em 1993.

Santiago Castro-Gómez traduziu a obra para o espanhol sob o título Manifiesto inaugural del Grupo Latinoamericano de Estudios Subalternos, compondo uma coletânea de artigos coordenada por Eduardo Mendieta e aquela tradutora, em 1998. O artigo de Walter Mignolo soava como a voz mais crítica e radical do grupo, apartando-se dos estudos subalternos “originais" e buscando um locus de enunciação na América Latina, sem se espelhar na resposta indiana ao colonialismo, uma vez que a história desse continente ainda estava oculta (BALLESTRIN, 2013).

Posteriormente, Grosfoguel $(2008,115,147)$ elenca motivos de descontentamento com aquele grupo: a incapacidade de romper com a episteme (centrada no Norte) dos estudos regionais estadunidenses e subalternos indianos. Diante das ressalvas, sem aprofundar e radicalizar sua crítica ao eurocentrismo, o grupo GLAES não sobreviveu aos primeiros

2“[...] O Império (se é que existe) opera dentro da lógica global ou da marca d'água da raça e colonialidade. É por isso que os muros e as fronteiras do Ocidente continuam a reforçar-se, com tanta facilidade, em tantos locaischave do mundo moderno; também é por isso que os EUA são capazes de se referir explicitamente a alguns países como sendo malévolos e que, por exemplo, assistimos actualmente, em países como a França, a uma caça às bruxas que persegue muçulmanos críticos da nova direita.” (MALDONADO-TORRES, 2008, p. 94, grifo nosso).

3 “ [...] O grupo foi formado em um diálogo sul-sul com os indianos em uma universidade do norte, como afirma a nicaraguense Ileana Rodríguez. O leque de influências e trânsitos do grupo é bastante amplo: estudos subalternos, estudos culturais, literários, pós-modernos e críticos latino--americanos, pós-estruturais, pós-marxistas, feministas. Ele foi responsável por inserir a América Latina no debate pós-colonial, marcando suas diferenças com o projeto asiático. Ileana Rodríguez é a editora da coletânea The Latin American subaltern studies reader, publicada em 2001 pela Duke University Press." (BALLESTRIN, 2013, p.98) 
encontros de 1998, mesmo ano de dissolução e estruturação do grupo Modernidade/Colonialidade a partir de seminários, diálogos e publicações. Todavia, a maioria do GLAES não migrou para esse grupo que traz como um dos fundadores Mignolo.

O último encontro do GLAES ocorreu em outubro de 1998 com latinos e indianos subalternos em um congresso na Universidade de Duke (GROSFOGUEL, 2008, p.115). Os primeiros passos do M/C se deram em um evento na Universidad Central de Venezuela, em Caracas, com apoio da Consejo Latinoamericano de Ciencias Sociales (CLACSO), organizado pelo sociólogo Edgardo Lander e incluindo convidados como Walter Mignolo, Aníbal Quijano, Enrique Dussel, Arturo Escobar e Fernando Caronil ${ }^{4}$.

Outro evento convergente, ainda em 1998, diz respeito ao Coloniality Working Group, composto por estudantes e professores entorno da Análise do Sistema-Mundo do sociólogo estadunidense Immanuel Wallerstein, com presença de Ramón Grosfoguel e Augustin LaoMontes que organizaram o congresso internacional Transmodernity, historical capitalism, and coloniality: a postdisciplinary dialogue, em Binghamton, no EUA, tendo como convidados Dussel, Mignolo Quijano e Wallerstein, momento que reuniu pela primeira vez esses três teóricos do grupo $\mathrm{M} / \mathrm{C}$ no debate das heranças coloniais em diálogo com a análise de Wallerstein (CASTRO-GÓMEZ; GROSFOGUEL, 2007, p. 10). Nesse sentido:

[...] A consciência dos padrões de longo prazo de racialização, dominação e dependência, testados e postos em prática no contexto da conquista das Américas (mas que obviamente se não restringiram ao território americano) foi o que levou alguns académicos da América Latina e alguns académicos 'latinos' dos Estados Unidos, incluindo gente envolvida em confrontos indígenas na América do Sul, a entrar num diálogo crítico com perspectivas como as defendidas por Quijano ou Wallerstein, que identificam a existência de padrões de relações de poder de longo prazo naquilo que viemos a chamar modernidade. Se a teoria pós-colonial, por um lado, constituiu um enorme contributo para a compreensão da modernidade na sua relação com a experiência colonial e a deslocação do Estado-nação enquanto unidade de análise - ideias que ainda têm de ser assumidas por inteiro a partir da perspectiva do sistema mundo - por outro lado, ela também se arrisca a tomar como certa a narrativa da modernidade (MALDONADO-TORRES, 2008, p. 86).

As primeiras publicações do grupo Pensar (en)los intersticios. Teoría y Práctica de la crítica poscolonial (1999) e La reestructuración de las ciencias sociales en América Latina (2000) resultaram da articulação de uma cooperação entre a Universidad Javeriana de Bogotá, Duke University, University of Carolina e a Universidad Andina Simón Bolivar, na

4Que gerou uma importante produção para o grupo naquele momento, o livro La colonialidad del saber: eurocentrismo y ciencias sociales, editado por Lander e publicado na Argentina, em Buenos Aires, no ano 2000. 
oportunidade do simpósio internacional na Pontificia Universidad Javeriana da Colômbia, em 1999, organizado por Santiago Castro-Gómez e Oscar Guardiola, com a presença de Mignolo, Lander, Coronil, Quijano, Zulma Palermo e Freya Schiwy (BALLESTRIN, 2013, p. 97).

Dos anos 2000 a 2006, Ballestrin observa que se recepcionou e dialogou-se nas sete reuniões e encontros oficiais com Javier Sanjinés, Catherine Walsh, Nelson Maldonado-Torres, José David Saldívar, Lewis Gordon, Boaventura de Sousa Santos, Margarida Cervantes de Salazar, Libia Grueso, Marcelo Fernández Osco.

A indicação, não incontestável, dos principais membros do grupo são Aníbal Quijano, Enrique Dussel, Walter Mignolo, Immanuel Wallerstein, Santiago Castro-Gómez, Nelson Maldonado-Torres, Ramón Grosfoguel, Edgardo Lander, Arturo Escobar, Fernando Caronil, Catherine Walsh, Boaventura de Sousa Santos e Zulma Palermo, sendo identificados outros estudiosos como associados ao grupo, como Jorge Sanjinés, Ana Margarita CervantesRodríguez, Linda Alcoff, Eduardo Mendieta, Elina Vuola, Marisa Belausteguigoitia e Cristina Roja.

Portanto, para discorrer sobre a perspectiva descolonial é indispensável conhecer o projeto Modernidade/Colonialidade (M/C), considerando-se que apenas nas duas últimas décadas o agrupamento de pensadores latino-americanos em universidades das Américas, organizados em torno do Projeto M/C, galgou visibilidade no final dos anos 1990 (BRAGATO, 2014, p. 210), estruturando, assim, as bases de um novo pensamento crítico latino-americano apoiado na análise dos processos de dominação (SOARES; RODRIGUES, 2016, p. 483).

$\mathrm{O}$ projeto $\mathrm{MC}$ não se enquadra em uma história linear de paradigmas ou epistemes; se assim o fosse, se integraria na história do pensamento moderno. Arturo Escobar (2003, p. 69), em um estudo geral, apresenta esse coletivo chamando-o de programa de pesquisa Modernidade/Colonialidade $(\mathrm{M} / \mathrm{C})$, com controvérsias e tensões, uma comunidade de argumentação, como denomina o antropólogo brasileiro Gustavo Lins Ribeiro. Escobar aponta quatro características possíveis ao M/C: (i) a transdisciplinaridade; (ii) a América Latina como uma perspectiva epistemológica; (iii) uma comunidade de comunicação; e (iv) a posição política alinhada com os atores subalternos.

Os estudos decoloniais ${ }^{5}$ fundados nos processos de independência, não se restringem aos estudos das ex-colônias, mas abrangem processos de trocas desiguais e de marginalização

50 "s" do termo "decolonial" é eliminado por Catherine Walsh para marcar uma distinção com o prefixo "des" do espanhol, pois o decolonial denotaria um caminho de luta contínua para construções alternativas, e não extirpar o momento colonial de um outro momento não colonial que expressa o "des". Considera "decolonial" como um neologismo para denotar o processo de luta, um caminho contínuo de alternativas. 
derivados do capitalismo e do colonialismo. Em luta contra políticas econômicas capitalistas, os estudos propõem uma "ampliação das bases democráticas das sociedades descolonizadas ou não" (SOARES; RODRIGUES, 2016, p. 497).

Aquilo que tem sido denominado de pensamento descolonial está mais ligado aos estudos realizados pelo chamado grupo Modernidade/Colonialidade, formado basicamente por pensadores latino-americanos ou indivíduos comprometidos com a realidade latino-americana e que propõem uma ruptura mais radical, chamada de desobediência epistêmica em relação ao saber canônico europeu, mesmo em sua vertente mais crítica, como a Escola de Frankfurt ou o pós-estruturalismo, por exemplo (BRAGATO, 2014, p. 210). A identidade e vocabulário próprio do grupo com o compartilhamento de noções, raciocínios e conceitos oportuniza a renovação teórica e utópica nas ciências sociais da América Latina no século XXI (BALLESTRIN, 2013, p. 99).

O pensamento descolonial, tendo grande influência da matriz teórica indiana dos estudos pós-coloniais, guarda íntima relação temática com as teorias pós-coloniais. Ambos têm dado visibilidade à dimensão colonial da modernidade e sinalizado para o caráter eurocêntrico das formas de conhecimento dominante. Paralelamente, a tradição teórica ocidental sustenta que a modernidade é um fenômeno puramente intra-europeu, constituído a partir da Reforma Protestante, Revolução Francesa e Revolução Industrial, e que, posteriormente, se estendeu a todo mundo (BRAGATO, 2014, p. 211).

A discussão das perspectivas intra-modernas, tendências dominantes no estudo da modernidade, despertou nesse grupo de latino-americanos e latino-americanistas a necessidade de uma nova compreensão da modernidade que introduz um contraste substancial em relação aos enfoques dominantes da modernidade (ESCOBAR, 2003, p. 54).

Escobar (2003, p. 64) detecta a dificuldade de superação, por teóricos europeus e euroamericanos, da concepção de modernidade desde um pensamento de fronteira possibilitado pela perspectiva de uma diferença colonial. Um limite estrito encontrado por Mignolo e Dussel à desconstrução e às críticas eurocêntricas seria a reflexão que parte de categorias eurocêntricas como liberalismo, marxismo, pós-estruturalismo etc., apontadas como cegas à diferença colonial (epistemológica e cultural).

De outro modo, coloca-se o foco modernidade/colonialidade. O grupo de teóricos latino-americanos constrói uma rede de histórias locais/globais como alternativa à totalidade imputada pela modernidade. Esse pensamento alternativo sobre é diferente desde uma exterioridade ao sistema mundo moderno é a possibilidade, através das lentes da colonialidade, 
de um questionamento das origens espaciais e temporais da modernidade. Com isso, propõe um pensamento desde a diferença e para a construção de mundos locais e regionais alternativos (ESCOBAR, 2003, p. 59, 61, 68).

O pensamento alternativo reavalia as substantivas experiências de descolonização, da rebelião de Tupac Amaru e a revolução haitiana de independência de 1804 até os movimentos/lutas de contestação colonial/anticoloniais dos anos 60 como fontes de visão para o futuro opostas às convencionais, como as revoluções francesa e estadunidense, tendo-as como força epistemológica e pensando-as com a teoria desde a práxis política dos grupos subalternos (ESCOBAR, 2003, p. 61).

A unidade analítica própria dessa perspectiva é a modernidade/colonialidade, sendo essa última constitutiva da primeira. A segunda conclusão é a concepção da diferença colonial como espaço epistemológico e político privilegiado. Por meio de diferentes enfoques, algumas diferenças são exploradas como a economia política de Quijano, uma filosofia da libertação de Dussel, literatura e epistemologia de Mignolo.

Diferentemente dos estudos latino-americanos nos Estados Unidos, enquanto perspectiva epistemológica, o $\mathrm{M} / \mathrm{C}$ recusa-se a colocar a América Latina como objeto de pesquisa, já que entende que se trata de um espaço geo-histórico com e em distinta genealogia crítica do pensamento, propondo uma alternativa para a genealogia das ciências sociais modernas basilares dos estudos latino-americanos nos Estados Unidos. Entraves epistemológicos como estes surgem como paradigmas complementares, mas distintos.

Pode-se caracterizar o programa de investigação M/C como um exercício de sociologia do conhecimento atenta a uma análise discursiva produzida por essa perspectiva epistemológica. Para tanto, não há relação com nacionalidade ou lugar geográfico. É uma abordagem praticada em múltiplos espaços, constituindo elaborações contra-hegemônicas frequentemente constituídos por discursos imperialistas internos ou externos (ESCOBAR, 2003, p. 69).

Walsh (2010) pontua que o de-colonial é uma compreensão crítica e consciente do passado e do presente que se abre e orienta questões, perspectivas e trajetórias. Não se refere a uma nova linha ou paradigma de pensamento. Conforme observa as palavras de Jacqui Alexander, é uma forma de incitar metodologias e pedagogias que transpõem as fronteiras fictícias da exclusão ou marginalização para a configuração de outras formas de ser, pensar, questionar, pesquisar, ver, saber, sentir, escutar e estar, as quais desafiam a razão única moderna 
ocidental, matriz colonial de poder e dominação ${ }^{6}$ desde e com racionalidades, conhecimentos, práticas radicalmente distintas. Reaprender para aprender as contribuições partem de três eixos: intercultural, inter-epistêmico e de-colonial.

Todavia, o grupo M/C, que tem sua origem na década de 1990, nos Estados Unidos, carrega a herança de sua primeira língua com a ideia elaborada por esse coletivo entorno do "decolonial". Esse termo utiliza o prefixo de inglês, referência à língua de nascença decoloniality com o prefixo de proveniente do inglês e similar ao "des" do português e do espanhol - o indesejável prefixo que Walsh objetiva eliminar a referência (BALLESTRIN, 2017, p. 108; MIGNOLO, 2010, p. 19).

Ballestrin (2017), ao arguir uma diferença histórica e temporal, indica que o termo "decolonial" é elaborado pelo grupo Modernidade/Colonialidade com a ideia de transcender a colonialidade, enquanto o "descolonização" seria a superação do colonialismo, existindo autores que utilizam a expressão descolonização diferenciando com recursos de estilo (itálico) tanto para aquele sentido indicado de "decolonialidade" (projeto político-teórico alternativo) ou de "descolonização" (processos de luta das colônias pela descolonização).

A opção não é unânime. No geral, se aceitam os dois termos para compreendê-los nesse lugar que ocupa em outra genealogia do pensamento. Neste trabalho, a presença do termo "decolonial" demarca a utilização por alguns autores citados conforme a fonte indicada e expressa o termo "descolonização" utilizado em português como opção argumentativa da autora.

O projeto é concebido como uma descolonização epistemológica. A América Latina, que aflora como uma política da diferença, consciente da diferença constitutiva que a

6"Entendemos por esta matriz colonial, el sistema de clasificación jerárquica racial civilizatoria, que ha operado y opera en distintos ordenes de la vida, incluyendo con relación a identidades sociales (la superioridad del hombre blanco heterosexual), al ámbito ontológico-existencial (la deshumanización de pueblos indígenas y negros), epistémico (el eurocentrismo como perspectiva única de conocimiento así descartando otras racionalidades epistémicas), y cosmológica (el control y/o negación de las bases ancestrales-espirituales-territoriales-vivenciales que rigen los sistemas de vida de los pueblos de la diáspora Africana y de Abya Yala) (Quijano, 2006; Garcés, 2009). En el centro o corazón de esta matriz ubicamos el capitalismo como modelo único civilizatorio; la clasificación social, la noción de «humanidad», la perspectiva de conocimiento y el prototipo de sistema de vida impuestos que atañen a y se definen a partir de este centro capitalístico-civilizatorio. Como bien argumenta Quijano, por servir a los intereses tanto de la dominación social como de la explotación del trabajo bajo la hegemonía del capital, «la 'racialización' y la ‘capitalización' de las relaciones sociales de estos patrones de poder, y el 'eurocentramiento' del su control, están en la base misma de nuestros actuales problemas de identidad», como país, «nación» y Estado (Quijano, 2006). Por eso mismo, consideramos esta perspectiva como fundamental.” (WALSH, 2010, p. 221) 
circunscreve e a produz historicamente, é uma referência interessante para pensar a possibilidade de uma/s América/s Latina outra/s ${ }^{7}$.

Para não correr o risco de colonização intelectual, a crítica ao pós-colonialismo promovida pela perspectiva descolonial sistematiza outras bases e categorias interpretativas desde a realidade da América Latina, afastando-se de qualquer tipo de conhecimento que proponha a universalização.

O descolonial como rede de pesquisadores é recente, todavia, essa caracterização do grupo não deve reduzi-la a isto. Além de projeto acadêmico, o descolonial é uma prática de oposição e intervenção protagonizada desde o primeiro sujeito do sistema mundo moderno/colonial que ocorreu com a invasão da América em 1492, início da Era do Sexto Sol, ${ }^{8}$ de acordo com a cosmovisão indígena.

Portanto, o descolonial não corresponde à citação de seus autores ou de conceitoschave, nem é uma espécie de universalismo abstrato que configura um novo colonialismo intelectual exercido pela América Latina. Ensaia um diálogo entre povos colonizados ou sob domínio da colonialidade, propondo a possibilidade de construção de uma rede planetária pela justiça, igualdade e diversidade epistêmica.

Para tanto, o ponto central do projeto político-acadêmico do descolonial é o reconhecimento de múltiplas e heterogêneas formas de dominação colonial na fronteira interna (negros e indígenas no Brasil) e externa (Américas), a diferença colonial exposta na fronteira, bem como a reação à colonialidade do poder (GROSFOGUEL; COSTA, 2016, p. 20).

Como observa Wolkmer (2015, p. 40), ter-se-á que uma real teoria revolucionária requer um postulado da organização e ação política, uma teoria crítico-prática. Diante dos problemas em que a modernidade não concede soluções modernas, há a necessidade do

7Um outro mundo é possível: essa reflexão envolvia o primeiro Fórum Social Mundial (FSM), ocorrido na cidade de Porto Alegre, em 2001. Um espaço de reflexão que sinalizava a importância de uma forma contra-hegemônica de globalização em face da versão impulsionada pelo capitalismo global, o neoliberalismo. Boaventura de Sousa Santos observa que não se tratava do primeiro, mas certamente o primeiro sinal consistente de inserção da ação dos movimentos sociais e organizações sociais, que lutavam em diferentes regiões do mundo, na agenda internacional. E, por mais de 10 anos, sempre atraindo novos movimentos e organizações. Era sintomático e otimizador da esperança que permeia os grupos sociais oprimidos, como um apelo a partir da América Latina, única região do mundo que havia a tradução mais consistente dessa esperança com a emergência de governos mais progressistas. Todavia, no final dos anos 2000, o neoliberalismo, munido do capital financeiro global, ataca as políticas sociais e a própria democracia. Com isso, o FSM precisaria se reinventar diante das condições e desafios presentes para tomar decisões políticas. É o que se aguarda do próximo FSM de Salvador (SANTOS, 2017).

8Conforme interpretação asteca, no tempo da invasão começa o Sexto Sol que tem o capital como deus idolatrado por aqueles recém-chegados do Oriente. Nessa era, o ritual exige o sacrifício dos povos desse "novo" continente, uma dor necessária para o processo de "modernização". O Sexto Sol ou a época da servidão corresponde à colonização. Sem entender o mundo "argumentativo" do outro, nega e destrói a sua sabedoria (DUSSEL, 1993, p. 122). 
desenvolvimento de um raciocínio "para uma teoria crítica alternativa/descolonial” no atual paradigma da humanidade. Nesse sentido, essa mudança da crítica convencional (natureza etnocêntrica) para outro tipo de conhecimento insurgente e alternativo faz-se imprescindível o reconhecimento dos "ausentes da história".

Essa teoria crítica descolonial deve promover o deslocamento pedagógico "para construção de uma concepção crítica descolonial, pluralista e intercultural enquanto expressão de libertação humana e das mudanças sociais em contextos periféricos, do que presentemente se convencionou denominar Sul global" (WOLKMER, 2015, p. 47).

Como propósito de deslocamento pedagógico, parte-se do encobrimento do outro, colocado na periferia. Desde então esquecidos, conforme a cosmovisão indígena no novo momento cósmico-histórico do "mundo" que nasce em 1492. Perante essa "nova ordem mundial" no Sexto Sol, sem uma suficiente argumentação, o poder advindo da conquista interrompe o "diálogo argumentativo" e deriva na doutrinação. É a dominação pelas mãos do homem moderno (DUSSEL, 1993, p. 140).

No Ocidente, a nova visão mundial da Modernidade que desenvolveu o "ego" europeu, até então periférico do mundo muçulmano, se deu com a conquista do México enquanto primeira forte experiência desse ego, residindo no Outro a alteridade essencial da Modernidade. Nessa nova época, há a metamorfose de um novo fetiche, o capital. A periferia mundial é imolada num ato sacrificial no novo altar ao novo deus (DUSSEL, 1993, p. 23, 34, 114).

Dussel $(1993$, p. $67,79,90)$ nega a validade do conceito de "encontro" ao significado de 1492, já que remete a um "encobrimento", uma vez que se serviu da violência no processo de "inclusão" do outro na "comunidade de comunicação". Portanto, metodicamente, são necessários novos olhos para corrigir os desvios do eurocentrismo, olhos desde "os de baixo".

Dessa forma, a partir da América se constitui um Ego individual e coletivo, Quijano (2000, p. 215, 216) pontua:

Hay, por supuesto, una relación umbilical entre los procesos históricos que se generan a partir de América y los cambios de la subjetividad o, mejor dicho, de la intersubjetividad de todos los pueblos que se van integrando en el nuevo patrón mundial. Y esos cambios llevan a la constitución de una nueva subjetividad, no sólo individual, sino colectiva, de una nueva intersubjetividad. Esto es, por lo tanto, un fenómeno nuevo que ingresa a la historia con América y en ese sentido hace parte de la modernidad. Pero cualesquiera que fuesen, esos cambios no se constituyen desde la subjetividad individual, ni colectiva, del mundo preexistente, vuelta sobre sí misma o, para repetir la vieja imagen, esos cambios no nacen como Minerva de la cabeza de Zeus, sino que son la expresión subjetiva o intersubjetiva de lo que las gentes del mundo están haciendo en ese momento. 
Desde 1492, no tempo do Sexto Sol, a outra face invisível da Modernidade - o povo latino-americano, o "bloco social" dos oprimidos - cria sua própria cultura, mas a modernização ignora a sua própria história. Ainda é difícil para esse povo realizar a Modernidade que sempre lhe explorou, oprimiu, pagou com a morte a cumulação do capital original para o desenvolvimento dos países centrais. Portanto, o ato de libertação precisa transcender o mito irracional que subsiste no capitalismo e na modernidade (DUSSEL, 1993, p. $151,153,172)$.

Ao trazer em relevo a interpretação não europeia nos mundos periféricos, Dussel objetiva introduzir uma teoria do diálogo que leve em conta que a filosofia da libertação ${ }^{9}$ afirma a razão enquanto faculdade com capacidade de diálogo, o discurso intersubjetivo estabelecido com a razão do outro, alternativa. Essa razão visa afirmar (subsumir) a emancipação racional da ilustração e da modernidade como transmodernidade. O projeto libertador tenta superar a modernidade. É um projeto de libertação e "transmodernidade". É um projeto de racionalidade ampliada, onde a razão do outro tem lugar na "comunidade de comunicação" para participar como igual e, ainda, no respeito a sua alteridade (DUSSEL, 1993, p. 173, 174).

Todavia, a colonialidade do poder põe em relevo a estrutura do poder colonial a partir do permanente conflito das relações e domínio colonial desde 1492. "Desenvolvimento" tem sido o termo chave do discurso político, mas a dependência histórica e estrutural, os modos de exploração e dominação, bem como recursos de produção, distribuição e apropriação do produto não se alteraram. $\mathrm{O}$ discurso virtual oficial sempre reaparece como um fantasma do passado (QUIJANO, 2014, p. 21).

As categorias epistemológicas, antropológicas, políticas e históricas do pensamento europeu produzidas desde a hegemonia Europeia sobre o resto do mundo funcionam como mecanismo de descarte de outras formas de conhecimento, no intento de se ter um único conhecimento insuperável. Entretanto, dividiu-se o mundo em dois com uma linha invisível,

9 No final da década de 1960, inicia-se a desmistificação de 'heróis' nacionais concebidos pelos modelos neocoloniais que se esgotavam com a nova visão sobre a cultura no desenvolvimento da filosofia da libertação. Com origem na invasão da América em 1492, uma cultura 'imperial' (de 'centro'), em um "diálogo' assimétrico de dominação global, exploração e aniquilação, confronta as culturas 'periféricas' da América Latina, África, Ásia e Europa Ocidental. Somam-se as elites educadas pelas culturas 'imperiais' que a reverberam distanciando-se do próprio 'povo', tendo-os como refém de sua política dependente. "A filosofia latino-americana como filosofia da libertação descobria seu condicionamento cultural (pensava-se a partir de uma cultura determinada), mas também articulada (explícita e implicitamente) a partir dos interesses de classes, grupos, sexo, raça etc. determinados. A location havia sido descoberta e era a primeira questão filosófica a ser tratada. O diálogo intercultural havia perdido sua ingenuidade e passou a ser compreendido como sobredeterminado por todo o período colonial. De fato, em 1974, iniciamos um 'diálogo' intercontinental 'Sul-Sul' entre os pensadores da África, Ásia e América Latina, cuja primeira reunião foi realizada em Dar-Es-Salaam (Tanzânia) em 1976. Esses encontros deram-nos um novo panorama sobre as culturas da humanidade." (DUSSEL, 2016, p. 52). 
sendo os dois lados modernos. A linha abissal, conforme nomeia Boaventura de Sousa Santos ${ }^{10}$, separa os conhecimentos a partir de critérios científicos de verdade e aos conhecimentos alternativos da filosofia e da teologia: conhecimento científico e conhecimentos populares, leigos, plebeus, camponeses ou indígenas (BRAGATO, 2014, p. 212).

Destarte, a formação de um novo padrão de poder desde a América afeta o mundo. Essa percepção de uma mudança histórica é elemento base da nova subjetividade. Nesse novo tempo, percebe-se que

(...) la historia puede ser percibida ya no sólo como algo que ocurre, sea como algo natural o producido por decisiones divinas o misteriosas como el destino, sino como algo que puede ser producido por la acción de las gentes, por sus cálculos, sus intenciones, sus decisiones, por lo tanto como algo que puede ser proyectado, y, en consecuencia, tener sentido (QUIJANO, 2000, p. 216).

No contexto da globalização excludente, de diversas formas, constata-se uma ênfase na ratificação do fenômeno sociocultural que leva a um verdadeiro apartheid, intolerância e negação do outro. Na América Latina, Sacavino e Candau (2015, p. 12, grifo nosso) depreende-se que

[...] De ella se desprende que las relaciones interétnicas hayan sido una constante a lo largo de su historia, una historia dolorosa y trágica, principalmente en lo referente a los grupos indígenas y a los afrodescendientes.

Nuestra formación histórica está marcada por la eliminación física del 'otro' o por su esclavización que es, también, una forma violenta de negación de su alteridad. Los procesos de negación del 'otro' también se dan en el plano de las representaciones y en el imaginario social. En este sentido, el debate multicultural en América Latina nos confronta con esos sujetos históricos que fueron masacrados, que supieron resistir y que hoy continúan afirmando fuertemente sus identidades en nuestra sociedad, desde relaciones de poder asimétricas, de subordinación y de acentuada exclusión.

O tema da alteridade perpassa as diversas abordagens sobre o multiculturalismo.

Todavia, a construção da perspectiva é etnocêntrica, de maneira que a localização da relação entre "nós" e os “outros" parte de uma visão binária e dicotômica. Enquanto estes são maus, os

10 "O pensamento moderno ocidental é um pensamento abissal. Consiste num sistema de distinções visíveis e invisíveis, sendo que essas últimas fundamentam as primeiras. As distinções invisíveis são estabelecidas por meio de linhas radicais que dividem a realidade social em dois universos distintos: o 'deste lado da linha' e o 'do outro lado da linha'. A divisão é tal que o 'outro lado da linha' desaparece como realidade, torna-se inexistente e é mesmo produzido como inexistente. Inexistência significa não existir sob qualquer modo de ser relevante ou compreensível. Tudo aquilo que é produzido como inexistente é excluído de forma radical porque permanece exterior ao universo que a própria concepção de inclusão considera como o 'outro'. A característica fundamental do pensamento abissal é a impossibilidade da co-presença dos dois lados da linha. O universo 'deste lado da linha' só prevalece na medida em que esgota o campo da realidade relevante: para além da linha há apenas inexistência, invisibilidade e ausência não-dialética.” (SANTOS, 2007, p. 71). 
identificados como "nós" precisamos salvar os "outros", mesmo que seja violentamente (SACAVINO; CANDAU, 2015, p. 5, 6). Ainda é difícil para esse povo realizar a Modernidade que sempre the explorou, oprimiu, pagou com a morte a cumulação do capital original para o desenvolvimento dos países centrais (DUSSEL, 1993, p. 172).

\section{Pensamento descolonial: pensar desde a fronteira}

O pensamento descolonial é contra-hegemônico da modernidade. Nasce nos primórdios da Modernidade e inspira-se nos movimentos sociais de resistência gerados no contexto colonial. Sempre em condição periférica, velado pela retórica da modernidade, ocultado pela colonialidade, invisibilizado ${ }^{11}$.

Na primeira parte de um trabalho publicado em 2003, Arturo Escobar (2003, p. 52) traz uma visão geral do $\mathrm{MC}^{12}$. Cruzando Fronteira, a oportuna temática do Congresso de 2002 Conselho Europeu de Investigações Sociais da América Latina (CEISAL) em Amsterdam, demonstra a crescente relevância das fronteiras para o mundo das ciências sociais e humanas no que tange à construção dos imaginários políticos, sociais e culturais em uma nova perspectiva desde e sobre a Latino-américa naquela aurora do novo milênio. Foca em uma fronteira, nos conceitos de pensamento de fronteira e epistemologia de fronteira, associados ao esforço desse grupo (perspectiva emergente, porém coesiva). Argumenta que o programa ainda é relativamente desconhecido no mundo anglo falante por razões muito além do idioma, posto que o núcleo do programa constitui uma perspectiva desde a Latino-américa para esta e ao mundo das ciências sociais e humanas em conjunto.

A metáfora "fronteira", elaborada por Anzaldúa no domínio da colonialidade, constitui-se, em Mignolo, fronteira enquanto possibilidade de um pensamento outro que advém do interior exterior a fronteira. Esse pensamento de fronteira mover-se-ia além das categorias criadas e impostas pela epistemologia ocidental, alterando não apenas conteúdos, mas termos também (ESCOBAR, 2003, p. 66).

A ideia de desobediência epistêmica, desprendimento e abertura, proposta central do pensamento descolonial, relaciona-se com a necessidade de descolonizar o conhecimento,

11 “[...] origens da modernidade na conquista da América, o pensamento descolonial leva ao reconhecimento de dois fenômenos: a dominação do "outro" não europeu como uma dimensão necessária da modernidade e a existência de uma representação hegemônica e de um modo de saber que afirma a universalidade para a experiência europeia, o que pode ser chamado de eurocentrismo." (BRAGATO, 2014, p. 212).

12Enfatiza que é uma visão pessoal do trabalho desse grupo, desde sua participação e entendimento. 
tendo constatado uma face oculta e encoberta da modernidade, a colonialidade. Portanto, pensar desde a fronteira, conforme pontua Mignolo, se trata de percorrer outros lugares de memórias e feridas coloniais encobertas e descartadas pela racionalidade. É com a diferença colonial que a exterioridade expressa no bárbaro é selvagem, colonizada, e a identidade produzida pelo civilizado, racional (BRAGATO, 2014, p. 210, 214).

A concepção de pensamento de fronteira é externa à Ibero-américa. É um tipo que introduz a subalternização do conhecimento e da racionalidade. Desse projeto de Mignolo do pensamento de fronteira e da diferença colonial emerge uma genealogia das histórias locais voltadas a outros desígnios globais. Por meio de diferentes enfoques, algumas diferenças são exploradas. É o caso de Quijano com a economia política, de Dussel com uma filosofia da libertação e de Mignolo com literatura e epistemologia (ESCOBAR, 2003, p. 614).

Esse pensamento de fronteira propõe-se como um conhecimento subalterno emergente das fronteiras do sistema mundo colonial/moderno que articula o rompimento com a dominância do eurocentrismo. Está nos momentos de fratura do imaginário "sistema mundo". É uma epistemologia de e desde a fronteira, um pensamento desde outro lugar, move-se desde uma linguagem outra, uma lógica outra. Altera termos, não apenas conteúdos do discurso.

O movimento indígena ao pugnar por sua própria cosmologia econômica, social, educacional e subjetiva, seguido dos afro-descentes da América do Sul e Caribe, dos intelectuais islâmicos e dos árabes, expôs a fratura epistêmica descolonial. Esta tem retraído o idealismo do Estado da burguesia que identificou o Estado com uma etnia, tornando equivalente o poder deste povo e de seu Estado. Estes "dotados" de poderes funcionam a partir da cosmologia da teoria política ocidental com personagens como "Platão e Aristóteles a Maquiavel, Hobbes e Locke.” (MIGNOLO, 2008, p. 315).

É uma forma ética de pensar, não tem uma dimensão etnocida, nem objetiva expressar verdade ou corrigir erros. A localização na fronteira possibilita a dupla crítica do ocidentalismo/eurocentrismo e das mesmas tradições excluídas.

Todavia, Mignolo (ESCOBAR, 2003, p. 66) sugere, ao reconhecer a importância da crítica monotópica da epistemologia modernidade, o diálogo desta com o espaço epistemológico emergente da fronteira, tendente às transformações políticas e éticas. O discurso crítico da modernidade e o discurso crítico decorrente da diferença colonial que constitui o pensamento de fronteira precisam ser articulados para uma hermenêutica pluritópica, termo que adapta da hermenêutica diatópica de Raimon Panikkar. 
Portanto, a metodologia do pensamento de fronteira revela uma dupla crítica da modernidade desde a perspectiva da colonialidade, implicando no deslocamento e partida da crítica e da afirmação positiva de um modelo alternativo. A proposta desse pensamento propõese a romper com a estrutura formulada pelo eurocentrismo como única perspectiva epistemológica. Ao romper com a ideia de totalidade, introduz-se a ideia de redes para uma articulação que demanda princípios epistemológicos - o intitulado pensamento de fronteira.

A proposta não é fundamentalista ou essencialista, ao contrário, ela está em diálogo com a modernidade, sendo que esse diálogo ocorre desde as perspectivas subalternas. É a resposta epistêmica desse sujeito encoberto ao projeto eurocêntrico moderno. ${ }^{13}$ Nesse ponto, reside uma diferença relevante entre o projeto decolonial e as teorias pós-coloniais, pois para estas a fronteira ou entrelugar é o espaço de reinvenção das diferenças enquanto que o decolonial conecta o lugar e o pensamento, sendo também o lugar de enunciação do conhecimento.

Esse lugar, que incide sobre o corpo colonizado, é geopolítico (sistema mundo moderno/colonial) e marcado pelas hierarquias (racial, classe, gênero, sexual), tendo em vista que mesmo sendo uma localização particular, os paradigmas eurocêntricos hegemônicos colocam-se como universais, não localizados.

É uma rearticulação da diferença colonial que tem a pluralidade como um projeto universal. Articula-se o conhecimento subalterno e o hegemônico desde a perspectiva do subalterno. É a possibilidade de produção de totalidades alternativas ou uma alternativa à totalidade sob a relação mundialização/cultura. A mundialização frisa a multiplicidade de narrativas locais que contrastam e problematizam os desígnios globais; a homogeneização cultural da globalização. ${ }^{14}$

Em suma, o programa de pesquisa da modernidade/colonialidade elenca uma forma alternativa para as questões da modernidade, da globalização e do desenvolvimento, que não se limita na narração alternativa dos eventos, mas também de uma transformação epistêmica na perspectiva. Assim, é construída desde a periferia latino-americana do sistema mundo moderno-

13“[...] Podemos identificar, por exemplo, como pensamento fronteiriço as contribuições do indígena Felipe Guama Poma de Ayala, que, no início do século XVII, escreve Nueva crónica y buen gobierno, obra monumental relatando o desastre da colonização espanhola sobre o império inca e, ao mesmo tempo, indicando ao rei da Espanha o que deveria ser um bom governo a partir de uma perspectiva incaica (Poma de Ayala, 1980).” (GROSFOGUEL; COSTA, 2016, p. 19).

140 projeto zapatista seria um exemplo de pensamento de fronteira. Teria reelaborado o marxismo, o terceiromundismo e o indigenismo, sem corresponder à identidade de nenhum desses (ESCOBAR, 2003, p. 67). 
colonial como forma de explicar as dinâmicas do eurocentrismo na produção da modernidade e possibilidades de transcendê-lo. Mignolo (2010) aponta que esse enfoque teórico desde o Terceiro Mundo é uma teorização também para o Primeiro Mundo, de forma que a teoria crítica é posta e incorporada em um novo espaço neocultural e epistemológico.

É necessário corrigir e abordar uma lógica de produção histórica da diferença, como pontuou Castro-Gómez, para reconhecer o caráter parcial, histórico e heterogêneo das identidades, evitando a lógica modernista da alterização com as abordagens das identidades com postulados que derivam em um igualmente homogeneizado Outro moderno/europeu/norteamericano. Um outro absoluto. A noção de pensamento de fronteira ou de posicionamento de fronteira como chama Mignolo e Catherine Walsh (2003), respectivamente, parece evitar a antiga lógica, tendo em vista pautas como de gênero, o ambiente e a economia política.

Pensando em fronteira, é interessante a noção de fronteira interétnica para compreender a permeabilidade e as trocas oriundas desse lugar. A concepção de Frederik Barth (2000) indica dois pontos: a situação de contato e os aspectos da realidade das sociedades indígenas. Enquanto relações de "fricção", nota o contexto em que está imersa a comunidade, bem como as condições manifestas do domínio imposto expõem o caráter antagônico das relações interétnicas ali desenvolvidas que configuram a situação colonial e evidenciam a participação em grau variável da sociedade colonizada, diante da dupla realidade: sociedade global e situação colonial. Assim, as relações interétnicas têm suas duas ideias norteadoras: as relações de oposição histórica e estrutural; e a dinâmica do contato interétnico (CARDOSO DE OLIVEIRA, 1981, p. 21, 31).

Os dois pontos interessantes quanto ao caráter das fronteiras étnicas, como nota Barth (2000, p. 26, 35), são as distinções das categorias étnicas que se mantêm apesar do fluxo de pessoas no processo de exclusão e de incorporação, com alteração de participação e pertencimento na história de vida dos indivíduos; e a existência de relações sociais estáveis, persistentes e frequentemente vitais que atravessam fronteiras.

A delimitação da fronteira étnica corresponde ao "compartilhamento de critérios de avaliação e de julgamento". É essa dicotomização que os torna Outros, estranhos, implicando no reconhecimento de limitações. Todavia, não há mundos separados, grupos étnicos ilhados. Pensar de outro modo é ter implícita uma visão preconcebida dos fatores significativos desses grupos. Pressupõe a inexistência de problemas na manutenção das fronteiras, além de justificar que isso decorre do isolamento característico do grupo (BARTH, 2000, p. 28). 
A etnicidade apresenta-se como linguagem que remete a algo externo a ela e que permite comunicação. Nesse sentido:

[...] Pois enquanto forma de organização política, ela só existe em um meio mais amplo (daí, aliás, seu exacerbamento em situações de contato mais íntimo com os outros grupos), e é esse meio mais amplo que fornece os quadros e as categorias dessa linguagem. A cultura original de um grupo étnico, na diáspora ou em situações de intenso contato, não se perde ou se funde simplesmente, mas adquire uma nova função, essencial e que se acresce às outras, enquanto se torna cultura de contraste: este novo princípio que a subtende, a do contraste, determina vários processos. A cultura tende ao mesmo tempo a se acentuar, tornando-se mais visível, e a se simplificar e enrijecer, reduzindo-se a um número menor de traços que se tornam diacríticos (CARNEIRO DA CUNHA, 1986, p. 99).

A comunidade é como um símbolo. São nas suas relações sociais que se constituem os significados para os seus membros. Portanto, as suas peculiaridades e a realidade de suas fronteiras são suscetíveis de interpretação e atribuição de seus significados pelas pessoas da comunidade (COHEN, 1985, p. 87).

Desse modo, a fronteira interétnica reflete ainda o encobrimento desses sujeitos históricos desde o início do Sexto Sol, conforme interpretação alternativa. Não houve encontro, há uma violenta negação do mundo do Outro, sendo necessária a promoção de um raciocínio de uma teoria crítica descolonial, um outro tipo de conhecimento alternativo para reconhecer os "ausentes da história" e promover um deslocamento pedagógico que permita a construção de uma crítica descolonial, plural e intercultural, conforme nota Wolkmer (2015, p. 40).

\section{Elementos do discurso crítico do pensamento descolonial}

Duas ideias centrais são as principais críticas ao discurso dominante desde o pensamento descolonial: transmodernidade e geopolítica do conhecimento. É partindo dessas duas categorias que se compreende os fenômenos colonialidade do poder e a diferença colonial.

Em toda tradição do pensamento negro, constata-se a ideia expressa pelo conceito do termo "colonialidade", como em W.E.B. Du Bois, Oliver Cox, Franz Fanon, Cedric Robinson, Aimé Césaire, Eric Williams, Angela Davis, Zora Neale Huston, Bell Hooks etc. Entretanto, Immanuel Wallerstein é quem articula a ideia inscrita no conceito de colonialidade e Aníbal Quijano trabalha designando-o como colonialidade do poder (COSTA; GROSFOGUEL, 2016, p. 17). 
Nelson Maldonado Torres (2007, p. 131) diferencia-os: colonialismo como uma relação política e econômica de domínio de um povo sobre outro ou nação; colonialidade como a sobrevivência de um padrão de poder decorrente do colonialismo moderno. Resulta que a vida na modernidade é permeada de colonialidade uma vez que está entranhado nas raízes da sociedade e sobrevive apesar do término dos colonialismos modernos com a descolonização ou emancipação das colônias latino-americanas, asiáticas e africanas, nos séculos XIX/XX (SACAVINO; CANDAU, 2015).

Os conceitos de colonialismo e de colonialidade abordados por Quijano ao diferenciálos e relacioná-los, compreende aquele como um padrão de dominação e exploração, um processo de poder, enquanto que a colonialidade é uma característica do poder exercido nas relações de dominação colonial da modernidade que provém do colonialismo, mantido nas variadas formas de neocolonialismo global ou colonialismos internos (BRAGATO, 2014, p. 211).

A Colonialidade do poder, conceito proposto por Quijano (2000, p. 204), denota a estrutura de dominação que produz novas identidades históricas e sociais relacionadas, mutuamente e por associação, em torno da ideia de raça ${ }^{15}$ e divisão do trabalho desde a Conquista/Invasão/Ocidentalização às quais foram submetidas a América Latina, África e Ásia.

A subjetividade no Sexto Sol é construída pela colonialidade do poder. Há uma captura do imaginário do outro, sua ocidentalização, enquanto o colonizador produz a naturalização do seu próprio ao criar um fetichismo em torno de si como o cultural, sendo o eurocentrismo uma perspectiva de conhecimento entre europeus e seus educandos, havendo uma inviabilização e subalternização epistêmica, bem como negação e esquecimento de processos históricos de outros europeus. Nessa dinâmica, a colonialidade do poder significa a imposição naturalizada dos modos próprios do colonizador/invasor que reprime os outros modos de produção de conhecimento, saberes, mundo simbólico, imagens (SACAVINO; CANDAU, 2015, p. 101).

Das raízes da colonialidade, Mignolo observa que a prática epistêmica descolonial surgiu "naturalmente" como consequência da formação dessas estruturas de dominação, a que Aníbal Quijano chama de matriz colonial de poder e, por isso, tem como razão de ser e objetivo a descolonialidade do poder (BRAGATO, 2014, p. 211).

A articulação das formas históricas de controle do trabalho na relação capital/trabalho assalariado no novo padrão de poder mundial é constitutivamente colonial, pois se baseia em

15É uma categoria mental da modernidade (QUIJANO, 2000, p. 202). 
todas formas de trabalho não pagas submetidas às raças colonizadas e, posteriormente, o trabalho pago, agora assalariado, à raça colonizadora, os brancos. Os recursos e produtos do núcleo principal do caráter histórico do padrão de controle de trabalho é constituído a partir da América. Tal colonialidade do controle do trabalho determinou a distribuição geográfica das formas do capitalismo mundial, desde a partida colonial/moderno e eurocentrado, fazendo compreensível Raúl Presbish com sua imagem "Centro-Periferia" para descrever o pósSegunda Guerra Mundial, o conceito “moderno sistema-mundo" por Immanuel Wallerstein e o conceito capitalismo mundial de Karl Marx (QUIJANO, 2000, p. 208).

Com isso, o discurso crítico do pensamento descolonial problematiza o conceito de racionalidade, busca demonstrar que a aparente neutralidade representa um projeto de invisibilidade e opressão humana, reforçado pela ideia de raça e exercício de um poder que ignora outras formas de conhecimento, ou exclui a possibilidade de coexistência juntamente a outros tipos de conhecimento, tendo-se um conhecimento histórico e situado, razão pela qual as formas de compreensão estão, desde a modernidade, pautadas pelos padrões epistemológicos europeus, especialmente pelo racionalismo matriz colonial (BRAGATO, 2014, p. 220).

Desde a Europa, na condição de centro do capitalismo mundial, a incorporação ao sistema-mundo das outras regiões e populações implicou a reidentificação (junto) histórica com um novo universo de relações intersubjetivas de dominação, atribuindo-se novas identidades geoculturais. Como parte desse novo controle padrão de poder mundial, equivalente à articulação promovida nas formas de controle do trabalho, em um processo de expropriação/repressão/força, há as formas de controle das subjetividades, da cultura, do conhecimento, da produção do conhecimento (QUIJANO, 2000, p. 210).

O etnocentrismo, peculiar no caso europeu, tem fundamento e justificação na classificação racial universal. O sentimento da natural superioridade resulta de uma operação mental fundamental para o padrão de poder mundial, sobretudo nas relações intersubjetivas hegemônicas e, particularmente, na perspectiva de conhecimento com a produção de um novo ângulo temporal da história, e relocalização das perspectivas dos colonizados, criando uma trajetória que culmina na Europa. A representação da categoria com uma diferente natural se dá com essa trajetória naturalmente linear contínua europeia, que não é a mesma dos outros anteriores aos europeus, raças inferiores.

Em sua versão eurocêntrica, a modernidade e a racionalidade são imaginados como fenômenos, experiências e produtos exclusivamente europeus e, em uma relação binária do conhecimento europeu e não europeu, a categoria raça é basilar na codificação de um jogo de 
novas categorias: Oriente/Ocidente; primitivo/civilizado; irracional/racional; tradicional/moderno; mágico-mítico/científico. A única categoria reconhecida como o Outro da Europa ou do Ocidente foi o Oriente, os demais eram primitivos. Nas críticas à perspectiva histórica linear, Dussel (1993) observa a afirmação de Hegel ([1831]2008) sobre a história universal partir do Oriente (Ásia) ao Ocidente (Europa).

A reflexão do imaginário conflitivo surge com e da diferença colonial (MIGNOLO, 2005 , p. 32), tendo esta como eixo organizador contínuo a colonialidade do poder. Nos discursos pós-modernos, a diferença colonial (pagão, bárbaro, subdesenvolvido) é um lugar passivo. Na modernidade, esse lugar logrou visibilidade a partir dos movimentos de descolonização do final do século XVIII à segunda metade do século XX.

Nessa história das ideias do imaginário moderno/colonial, forjaram-se as histórias ou cosmologias nas Américas, Ásia e África, que resulta na duplicidade exterioridade exterior e exterioridade interior devido à densidade do imaginário hegemônico e a coexistência presente de articulações antigas, notável na percepção diferente diante do recorte do mundo moderno/colonial de quinhentos anos de descoberta/invasão das Américas pelos Estados que celebraram e pelos movimentos e intelectuais indígenas que retomam sua história e protestam ${ }^{16}$.

Embora o panorama de construção do mundo moderno moldado pela colonialidade do poder não se reduza a etnoracialidade, esta se tornou a engrenagem da diferença colonial com a expulsão dos mouros e judeus, os debates acerca do lugar dos ameríndios, a exploração e silenciamento de escravos africanos, uma vez que com e desde o circuito comercial do Atlântico é sinônimo de negritude. A construção da diferença colonial tem contribuições distintas, conforme colocadas pela colonialidade do poder: Sepúlveda e Las Casas, no século XVI; Guaman Poma de Ayala ou Ixtlixochitl. O sociólogo e intelectual negro W.E.B. Du Bois (1970) captura a formulação da subjetividade pela diferença colonial ao expressá-la no conceito dupla consciência, sendo a consciência dupla experimentada na condição de subalternidade colonial (MIGNOLO, 2005, p. 40).

Desse modo, o discurso crítico do pensamento descolonial desafia a concepção tradicional de modernidade com o conceito de transmodernidade, o qual discute as

16Das lições de Pedro Brandão, Soares e Rodrigues apontam que é no terceiro ciclo, nas Constituições da Bolívia e do Equador, baseadas na cosmovisão indígena que se busca a refundação do Estado Plurinacional, quando há a plenitude do novo constitucionalismo. Havendo nesses documentos um claro projeto descolonizador e intelectual, estabelecendo a jurisdição autônoma indígena igualitária com a ordinária, e no caso boliviano, o estabelecimento do Tribunal Constitucional Plurinacional, com representantes da jurisdição indígena e ordinária. (SOARES; RODRIGUES, 2016. p. 486, grifo nosso). 
inconsistências e demonstra razões de o discurso que se situa nas origens da Modernidade Ocidental ter-se projetado como um discurso hegemônico.

A modernidade pode ser conceituada de duas perspectivas diferentes: emancipação como "saída" da imaturidade por um esforço da razão como processo crítico, que proporciona à humanidade um novo desenvolvimento do ser humano. Esse processo ocorreria na Europa, século XVIII, cujos acontecimentos históricos essenciais são a Reforma, a Ilustração e a Revolução Francesa. É a perspectiva eurocêntrica, provinciana e regional. A segunda visão da "Modernidade", proposta por Dussel (1993), define-se pelo fato de o mundo moderno europeu ter se tornado o "centro" da História Mundial, posicionando as outras culturas do planeta na sua periferia. Esse conceito evidencia que o fenômeno da Modernidade não é meramente intraeuropeu, mas constituído pela sua face oculta: a colonialidade (BRAGATO, 2014, p. 216).

O problema da cultura da década de 1960 é retomado com as chaves de interpretações para uma nova aplicação chamada de "transmoderna", a superação do conceito de "pósmodernidade" 17 . As culturas universais assimétricas são pré-modernas, contemporâneas à Modernidade, e serão transmodernas. O conceito estrito é de uma novidade radical que surge da exterioridade, da alteridade, capaz de responder com soluções impossíveis para a cultura moderna única a partir de outro lugar correspondente a sua própria vivência cultural, other location.

É uma futura cultura transmoderna com pluriversalidade rica e fruto de um autêntico diálogo intercultural que parte de outro lugar, não é o mero diálogo de pressuposta simetria das culturas. Esse diálogo “é, sobretudo, um diálogo entre os 'críticos das periferias', um diálogo intercultural Sul-Sul, antes de ser um movimento para o diálogo Sul-Norte" (DUSSEL, 2016, p. 68). Transmodernidade envolve todos os aspectos além das estruturas valorativas da cultura euro-americana moderna em vigor nas culturas universais não europeias.

Desde o outro lado da linha abissal, no mundo periférico colonial, participam inclusive os "bárbaros marginalizados" desse fenômeno global, ainda que sua contribuição não seja reconhecida conforme indica Sartre no prefácio de Fanon (1968). O pensamento abissal expõe as duas principais linhas globais dos tempos modernos: o conhecimento e o direito moderno. Historicamente, eliminam as realidades do outro lado da linha, na zona colonial: a localização territorial originária coincide com um território social. É a negação da copresença que

17“O pós-modernismo é uma fase final da cultura moderna euro-americana, o 'centro' da Modernidade. As culturas chinesas e vedanta não poderão jamais ser pós-moderno-europeias, e sim outra coisa bem diferente e a partir de suas próprias raízes." (DUSSEL, 2016, p. 63). 
fundamenta a afirmação da diferença radical pré-estabelecida de verdadeiro e falso, legal e ilegal. Santos $(2007$, p. 73,77$)$ argui que a luta contra a cartografia metafórica de separação dos mundos exigiria um pensamento pós-abissal de grande esforço para a captação da totalidade desde o outro lado da linha, movimento que seria composto pelo "regresso do colonial e do colonizador" e pelo contra movimento "cosmopolitismo subalterno".

Para uma reflexão que explique aquele fenômeno que caracteriza a perspectiva eurocêntrica como uma constituição colonial, é necessário partir do conceito de geopolítica do conhecimento. Essa geopolítica descolonial é uma diversidade radical ${ }^{18}$, é o apelo de Nelson Maldonado-Torres (2008) ao articular a raça e o espaço à diferença do projeto da busca de raízes no Ocidente por diversos pensadores ocidentais que, em termos geopolíticos, situa a Europa como lugar epistêmico privilegiado, inspirado na geopolítica filosófica em Fanon, atenta ao caráter constitutivo da colonialidade e do projeto de modernidade europeia para refletir a produção do conhecimento.

O espaço e as relações geopolíticas afastam a ideia de sujeito epistêmico neutro ${ }^{19}$, sendo as reflexões respostas à experiência sentida sob o domínio universal. As graduais reflexões da modelagem do pensamento filosófico decorrente da forma das ideias sobre o espaço, embora na tradição filosófica ocidental se descarte esse contorno do pensamento devido ao lugar geopolítico e às ideias sobre o espaço que caracterizaria contingentes do raciocínio filosófico.

Em um autorretrato da modernidade há o estabelecimento da hegemonia epistêmica europeia enquanto os outros são relegados à condição de objetos do conhecimento. Alguns tem credibilidade epistêmica e outros não tem legitimidade para reflexões teóricas válidas. Quanto à constituição desse lugar epistemologicamente privilegiado:

18“[...] A diversidade radical implicaria um divórcio efectivo e uma crítica das raízes que inibem o diálogo e a formulação de uma geopolítica do conhecimento descolonial e não-racista" (MALDONADO-TORRES, 2008, p. 108, grifo nosso).

19“[...] Através de uma análise da implícita topologia do Ser de Heidegger, que se encontra inscrita na sua geopolítica, propus que a aparente neutralidade das ideias filosóficas pode muito bem esconder uma cartografia imperial implícita que funde espaço e raça. O racismo - sob a forma de esquecimento da condenação, racismo epistémico e muitas outras formas - está mais disseminado do que frequentemente se pensa. Está inscrito na cartografia do que muitas vezes se considera ser um pensamento crítico e um trabalho filosófico consistente. Para além das justificações biológicas de racismo, ou das justificações baseadas em diferenças de cultura ou maneiras de estar, é possível encontrar em algumas tendências influentes do pensamento ocidental uma justificação ontológica e epistemológica mais subtil. As consequências são nefastas, uma vez que a fusão de espaço e raça está por trás de concepções militares e imperiais da espacialidade, que tendem a dar um novo significado à formulação clássica de Santo Agostinho acerca das cidades terrenas e divinas: a diferença entre a Cidade de Deus e a Cidade Terrena dos Homens traduz-se na divisão entre as cidades imperiais dos deuses humanos e as cidades dos condenados. Infelizmente, a busca de raízes na Europa e as geopolíticas racistas costumam andar de mãos dadas." (MALDONADO-TORRES, 2008, p. 109). 
A expansão colonial europeia não provocou apenas a expansão global de seu domínio econômico e político, mas das concepções epistemológicas em todas as suas vertentes: desde a concepção de razão instrumental até as teorias políticas de governo. O conceito de geopolítica do conhecimento tem como finalidade desmistificar a lógica existente por trás das formas de produção e de adesão ao conhecimento. Por isso, enfatiza a ideia de eurocentrismo como uma espécie de conhecimento que afirma a universalidade da experiência histórica local da Europa e que se baseia no pressuposto de que esta ocupa uma posição superior em relação a outras culturas. A partir desta perspectiva, a Modernidade é o signo da superioridade europeia. Modernas concepções epistemológicas, antropológicas, políticas e históricas priorizam, respectivamente, as ideias de conhecimento científico, racionalismo, liberalismo e progresso. Eurocêntrica são, portanto, aquelas concepções que afirmam a universalidade desses modelos e concebido no eixo protestante da Europa central e norte (Inglaterra, França e Alemanha) (BRAGATO, 2014, p. 217, grifo nosso).

Maldonado-Torres (2008, p. 73) observa que a ontologia heideggeriana e a ética de Lévinas subsidiaram uma base sólida à viragem linguística e meios de ultrapassar os limites da ideia ocidental de Homem, todavia, mantiveram-se cúmplices de formulações espaciais de cariz imperial. Trata do esquecimento da colonialidade pela filosofia ocidental e teoria social contemporânea, tendo a viragem espacial da teoria social comparável à viragem linguística da filosofia ocidental. Em suas palavras:

[...] O esquecimento dos condenados faz parte integrante da verdadeira doença do Ocidente, uma doença do Ocidente, uma doença comparável a um estado de amnésia que por sua vez leva ao homicídio, à destruição e à vontade epistémica de poder - mantendo sempre uma boa consciência. A oposição à modernidade/racismo tem de saber lidar com esta amnésia e com a invisibilidade dos condenados (MALDONADO-TORRES, 2008, p. 83, grifo nosso).

Embora os conceitos de colonialidade sigam o radicalismo de Fanon, MaldonadoTorres (2008, p. 108) detecta a necessidade de "espaço à enunciação de cosmologias nãoocidentais e à expressão de diferentes memórias culturais, políticas e sociais”. Com isso, a realização do projeto de crítica das raízes, espaço vivaz da dominante topologia do Ser e da geopolítica racista do conhecimento, é a condição para projeto de busca de raízes. Além de Paris, Frankfurt, Roma ou Nova Iorque, o desafio é levar a sério também ao pensar em Fort-deFrance, Quito, La Paz, Bagdá e Argel como lugares de conhecimento. É pensar os mecanismos de criação da subordinação e naqueles presos a esta condição, as faces invisíveis produzidas pela modernidade.

O projeto de busca de raízes desde a Europa padece de uma amnésia sistêmica, pois rejeita a operação das relações geopolíticas na formulação da modernidade. "A diferença 
colonial como ponto de partida para o pensamento crítico" sinalizado por Fanon, "um conhecimento crítico das topologias do Ser e da sua geopolítica do conhecimento" expõe a funcionalidade das categorias da condenação: negro, judeu, muçulmano. Desse modo, para uma gramática descolonial, confrontada com as formas modernidade/racismo, tem-se formulado alguns conceitos como modernidade/colonialidade e colonialidade (poder, conhecimento e Ser).

Essa outra forma de pensar descolonial não é só de interesse restrito, mas busca intervir decisivamente nas ciências modernas para configurar outro espaço para a produção do conhecimento - uma forma distinta de pensamento, um paradigma outro, a possibilidade de falar sobre o "mundo e de outro conhecimento". Tais possibilidades, sugere o grupo MC, são projetadas no Fórum Social Mundial (Porto Alegre) (ESCOBAR, 2003, p. 53).

$\mathrm{Na}$ América Latina, Côrrea de Sousa, Soares e Rodrigues salientam que a partir da emergência desse outro momento, ganham força questões como inclusão do "outro", direitos indígenas, cultura popular latino-americana. Por causa dessa importância, a Filosofia da Libertação será tratada com o marco filosófico do novo constitucionalismo latino-americano. E pontua que embora seja relevante o embate entre imperialismo e soberania, tema sempre presente na região, não vislumbra uma contraposição entre as acumulações ampliadas e primitivas, pois a lógica do sistema capitalista é a produção da pobreza, e, com isso, a natural necessidade permanente de um mercado emergente, bases para o florescimento do imperialismo (SOARES; RODRIGUES, 2016, p. 483).

Com as novas matrizes teóricas, pretende-se romper com os conceitos impostos pela teoria liberal. O constitucionalismo contemporâneo distingue direitos fundamentais e direitos humanos, bem como os fundamenta na lógica do racionalismo da dignidade humana. Todavia, essa base do liberalismo é confrontada com os conceitos de bien vivir e com a natureza como sujeito de direito (BRAGATO, 2014, p. 495), posto que não se falaria mais em dignidade humana, mas sim na dignidade da vida. Portanto, seria no campo constitucional que haveria o grande reflexo ao passar a abrigar um novo espaço epistemológico construído por conhecimentos indígenas e ocidentais, configurando uma "inter-epistemologia", termo indicado por Walsh (SOARES; RODRIGUES, 2016, p. 495).

\section{Conclusão}


Este trabalho delineia uma gramática descolonial que confronta conceitos. Evidencia a permanente submissão da periferia global à mesma matriz de poder colonial, pós-período de colonialismo global, denominado de colonialidade global. A reflexão pós-colonial culminou na formação de grupos de estudos para a desconstrução da lógica colonial. Indicou o Grupo de Estudos da Subalternidade do Sul da Ásia (GESSA), que influenciou o agrupamento de uma perspectiva crítica desde a América Latina.

O Grupo Latino-Americano dos Estudos Subalternos (GLAES) foi a primeira forma de inserção da América Latina no debate pós-colonial. Diante de descontentamentos teóricos dos membros sobre a incapacidade de romper com a episteme do Norte global, logo se encerraram as atividades.

Surge o Programa Modernidade/Colonialidade que gira entorno da temática da descolonização. Suas características, conforme indica Arturo Escobar, são: a transdisciplinariedade; a América como uma perspectiva epistemológica; uma comunidade de comunicação; e posição política alinhada com os atores subalternos.

Justifica a opção pela perspectiva descolonial na medida em que há uma posição contra-hegemônica à matriz colonial que requer um deslocamento pedagógico para os processos liberatórios nos espaços da periferia global. Para tanto, parte do "encobrimento" do Outro desde o nascimento da modernidade em 1492, com a invasão da América. Segundo uma cosmovisão indígena, trata de uma "nova ordem mundial", é a Era do Sexto Sol. Esta representa o "fim" do mundo desses sujeitos.

É o momento de formulação do "ego" europeu. Metodicamente, são necessários outros olhos para retificar os desvios promovidos pelo eurocentrismo, desde "os de baixo". Estes constituem a outra face invisível da Modernidade.

Para os processos liberatórios de superação da modernidade, a perspectiva descolonial propõe pensar desde a fronteira, desde os movimentos sociais de resistência no contexto colonial. Tais processos dos sujeitos do Sul global delineiam outras narrativas que denotam o seu encobrimento. Com isso, os elementos críticos do discurso descolonial pontuados direcionam-se para os mitos produzidos por essa lógica colonial. Trata-se de uma desobediência epistêmica que perpassa os lugares encobertos pela racionalidade.

Desse modo, a pesquisa bibliográfica destaca os elementos críticos do pensamento descolonial, ou pensamento de fronteira como denomina Walter Mignolo, que pensam outros horizontes de fundamentação dos direitos humanos. Traz os conceitos introduzidos por esta 
perspectiva como a transmodernidade com Enrique Dussel; a colonialidade global com Aníbal Quijano; a geopolítica descolonial com Nelson Maldonado-Torres.

Mundializa ao tratar de variadas narrativas locais contrastantes e problematizadoras dos desígnios globais. Assim, formula alternativas para a modernidade, a globalização, o desenvolvimento.

Portanto, a partir de elementos do discurso crítico do pensamento descolonial, sinaliza a proposta de rompimento e a perspectiva de uma fundamentação alternativa dos direitos humanos nos espaços periféricos do Sul global, tendo em vista os fundamentos instituídos pela sociedade moderna/colonial.

\section{Referências}

BARTH, Frederik. O guru, o iniciador e outras variações antropológicas. (organização de Tomke Lask). Rio de Janeiro: Contracapa Livraria, 2000.

BALLESTRIN, Luciana. América Latina e giro decolonial. In: Revista Brasileira de Ciência Política. no 11. Brasília: 2013.

BALLESTRIN, Luciana. Para transcender a colonialidade. [Entrevista concedida a] Luciano Gallas e Ricardo Machado. IHU Online - Revista do Instituto Humanitas UNISINOS, São Leopoldo, ed. 431, 4 nov. 2013. Disponível em:http://www.ihuonline.unisinos.br/artigo/5258luciana-ballestrin Acesso em: 27 de Outubro 2017.

BRAGATO, Fernanda Frizzo. Além do discurso eurocêntrico dos Direitos Humanos: contribuições da descolonialidade. Revista Novos Estudos Jurídicos - Eletrônica, v. 19 $\mathrm{n}^{\mathrm{o}} 1$ - Jan-Abr 2014.

CARDOSO DE OLIVEIRA, Roberto. O Índio e o Mundo dos Brancos. Brasília: Editora UNB/Pioneira, 1981.

CASTRO-GÓMEZ, Santiago; GROSFOGUEL, Ramón. El giro decolonial. Reflexiones para una diversidad epistémica más allá del capitalismo global. Bogotá: Siglo del Hombre Editores, 2007.

COHEN, A. P. The Symbolic Construction of Community. In: The symbolic construction of community. London: Routledge, 1985.

COSTA, Joaze Bernadino; GROSFOGUEL, Ramón. Decolonialidade e perspectiva negra. In: Revista Sociedade e Estado. v. 31. nº 1. Brasília: 2016.

DUSSEL, Enrique. 1492: o encobrimento do outro (a origem do mito da modernidade). Conferências de Frankfurt. Trad. Jaime A. Clasen. Petrópolis: Vozes, 1993. 
DUSSEL, Enrique. Transmodernidade e interculturalidade: interpretação a partir da filosofia da libertação. In: Revista Sociedade e Estado. v. 31. nº 31. 2016.

ESCOBAR, Arturo. Mundos y Conocimientos de otro modo: el programa de investigación de modernidad/colonialidad latinoamericano. In: Tabula Rasa. no 1. Bogotá, 2003.

GROSFOGUEL, Ramón. Para descolonizar os estudos de economia política e os estudos póscoloniais: Transmodernidade, pensamento de fronteira e colonialidade global. In: Revista Crítica de Ciências Sociais. Coimbra: 2008.

MALDONADO-TORRES, Nelson. A topologia do Ser e a geopolítica do conhecimento. Modernidade, império e colonialidade. In: Revista Crítica de Ciências Sociais [online], 80, Coimbra: Editora de Estudos Sociais da Universidade de Coimbra, 2008.

MALDONADO-TORRES, Nelson. Sobre la colonialidad del ser: contribuciones al desarrollo de un concepto. In: CASTRO-GÓMEZ, S.; GROSFOGUEL, R. (Org.). El giro decolonial. Reflexiones para una diversidad epistémica más allá del capitalismo global. Bogotá: Siglo del Hombre, 2007.

MIGNOLO, Walter D. A colonialidade de cabo a rabo. In: A colonialidade do saber: eurocentrismo e ciências sociais. Perspectivas latino-americanas. CLACSO: 2005.

MIGNOLO, Walter D. Desobediência epistémica: a opção descolonial e o significado de identidade em política. In: Cadernos de Letras da UFF. N ${ }^{\circ}$ 34. 2008.

MIGNOLO, Walter D. Desobediencia epistémica: retórica de la modernidad, lógica de la colonialidad y gramática de la descolonialidad. Argentina: Ediciones del signo, 2010.

QUIJANO, Aníbal. Colonialidad del poder, eurocentrismo y América Latina. In: LANDER, Edgardo (org.). La colonialidad del saber: eurocentrismo y ciencias sociales. Perspectivas Latinoamericanas. Buenos Aires: CLACSO, 2000.

QUIJANO, Aníbal. Des/colonialidad y bien vivir - Un nuevo debate en América Latina. Lima: Universidad Ricardo Palma, 2014.

SACAVINO, Susana Beatriz; CANDAU, Vera Maria. Multiculturalismo, interculturalidad y educación: contribuciones desde América Latina. $1^{\mathrm{a}}$ ed. Bogotá: Ediciones Desde Abajo, 2015.

SANTOS, Boaventura de Sousa. Para além do pensamento abissal: das linhas globais a uma ecología dos saberes. In: Novos estudos CEBRAP, São Paulo, no 79, nov. 2007. Disponível em: https:/www.scielo.br/scielo.php?script=sci_arttext\&pid=S0101-33002007000300004 Acesso em: 16 de outubro de 2017.

SOARES, Danielle Cevallos Soares; RODRIGUES, Saulo Tarso. O novo constitucionalismo pluralista e experimental latino-americano: das narrativas coloniais da ditadura da maioria ao protagonismo pós-colonial da democracia popular. In: Hermenêutica, justiça constitucional e direitos fundamentais. Coordenação de Jorge Miranda [et al.]. Curitiba: Juruá, 2016. 
WALSH, Catherine. Estudio (inter)culturales en chave decolonial. $\mathrm{n}^{\circ} 12$. Tábua rasa. Bogotá: 2010.

WOLKMER, Antonio Carlos. Introdução ao pensamento jurídico crítico. $9^{\mathrm{a}}$ ed. São Paulo: Saraiva, 2015.

Data de recebimento: 04.04.2021

Data de aprovação: 28.05.2021 